\title{
Spatial distribution of heavy metals in water, soil and anurans' livers from Al-Hayr area - Riyadh, Saudi Arabia
}

\section{Authors Info}

K. A. Hasayen*, B. H. Al-Osaimi, A. M. Aljohany and H. M. Al-Jawdah

Department of Zoology, College of Science,

King Saud University,

Riyadh-11451, Saudi Arabia

${ }^{*}$ Corresponding Author Email : khasayen@ksu.edu.sa

Key words

Anurans,

Heavy metal pollution,

Relative accumulation indices,

Saudi Arabia,

Spacial distribution

\section{Publication Info}

Paper received : 23.03.2016

Revised received : 26.06 .2016

Re-revised received : 02.11 .2016

Accepted:09.11.2016

\section{Abstract}

Aim: There is increasing ecological and global health concern associated with environmental contamination by heavy metals. The main objective of the study was to analyze the spatial distribution of heavy metals in soil, water and anurans (frogs and toads) from four sites in Al-Hayr, Riyadh city.

Methodology: Seven heavy metals $(\mathrm{Cu}, \mathrm{Cr}$, $\mathrm{Cd}, \mathrm{Ni}, \mathrm{Zn}, \mathrm{Pb}$ and $\mathrm{Mn}$ ) were estimated to determine the concentration levels in soil, water and anuran liver tissues obtained from Al-Hayr region and arranged in descending order. Relative accumulation indices (RAl) were used to determine the bioaccumulation rate in anuran liver tissues.

Results: Soil and water results showed that no values appeared to be unusual, while two types of anurans (frogs and toads) were found having same RAI distribution and showed the same descending order. All values were statis tic a II y insignificant.

Interpretation: The perusal of data revealed that Al-Hayr was considered a nonpolluted area.

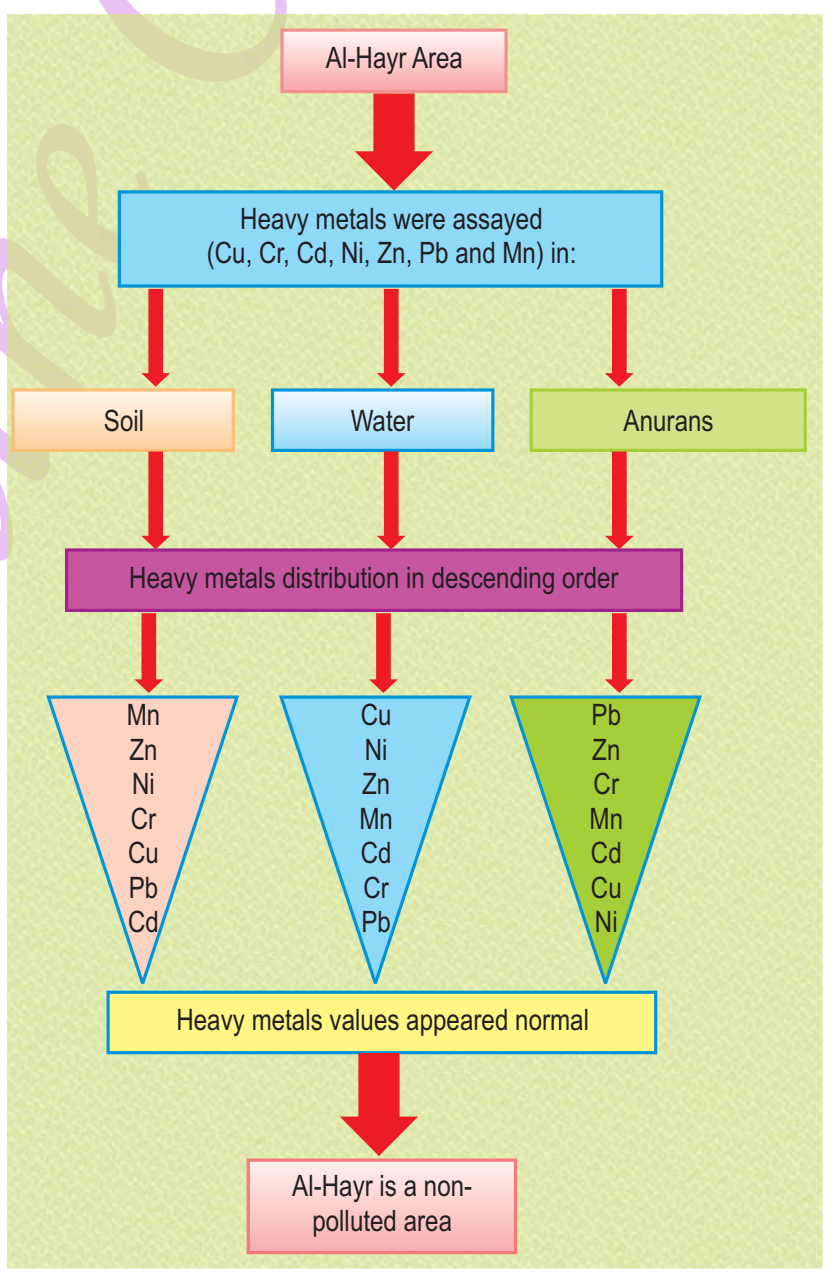




\section{Introduction}

There is an increasing ecological and global public health concern associated with environmental contamination by heavy metals. Although heavy metals are natural elements that are found throughout the earth's crust, most environmental contamination are due to anthropogenic activities such as mining and smelting operations, use of fertilizers and pesticides in agriculture (Serrano et al., 2012; Tchounwou et al., 2012). Anurans (Order of Amphibians) are closely linked to wetlands and their distribution depends upon various factors such as the type of aquatic habitats, temperature, type of substrate and vegetation in and around the ponds (Akram et al., 2015). The distribution and abundance of anurans provide valuable information for future monitoring and prediction, especially in areas of proposed or planned human activities. Anurans have permeable thin skin and eggs that may readily absorb toxic materials from the aquatic environment (Adlassing et al., 2013). The quality of habitat and water bodies where they live can affect their growth, development and survival (Halliday, 2008). Because pollution, pathogens and climate changes can all affect water quality, these factors can in turn affect anurans. Therefore, the use of amphibians (especially anurans) as models or indicators is required for studying responses to ecological change i.e., water quality and habitats (Akram et al., 2015; Hopkins, 2007).

Several studies have been published examining the effects of different heavy metals on living things. Adlassing et al. (2013) observed amphibians in severely contaminated habitats by mining for heavy metals in Central and Eastern Europe. They found that highly contaminated habitats and acidic water bodies are usually devoid of amphibians even though they may be present in the surroundings. They concluded that amphibians are capable of recognizing and avoiding extreme degrees of contamination. Although they observed that amphibians appear to possess a limited tolerance against heavy metals, they found metamorphosed toads with stunted fingers and toes, and frogs with albinism. Tyokumbur and Okorie (2011) investigated the macro and micro element accumulation in edible crabs and frogs (Rana esculentus and Xenopuslaevis) in water ecosystem, Ibadan-Nigeria. They found that the liver of the frogs contains higher concentrations of heavy metals than other organs (i.e., skin and intestines). Stepanyan et al. (2011) studied the effect of high concentrations of molybdenum, Chromium and Cadmium ions on the metamorphosis of Eurasian marsh frog Pelophylax ridibundus under laboratory conditions. They investigated the effects of these metals at concentrations exceeding maximum permissible concentration on the growth, survival and erythrocytes morphology of tadpoles and young frogs. Serrano et al. (2012) conducted a meta-analysis of experimental studies that measured the effects of different chemical pollutants and heavy metals on amphibian survival, mass, hatching, metamorphosis and abnormalities. They concluded that the overall impact of pollution on amphibians is moderately to large negative that it poses an important threat to amphibians and plays a role in their present global decline. The objective of the study was to analyze the spatial distribution of heavy metals in water, soil and anurans from four sites in Al-Hayr,Riyadh city.

\section{Materials and Methods}

Study area : Al-Hayr area is about $25 \mathrm{~km}$ south of Riyadh city; the capital of Saudi Arabia. In Al-Hayr area, a permanent stream has been developed from the rain water and $700,000 \mathrm{~m}^{3}$ of daily treated wastewater is discharged from three-mega tertiary treatment plants. In Al-Hayr area, Tamarix aphylla and Phragmites australis are most common plants, while irrigated farms have been established on clay soil and planting vegetables and palms, either using water from the water flow near their farms or depending on ground water for irrigation. The mean minimum and maximum temperature in Al-Hayr area ranges between 5.1$23.5^{\circ} \mathrm{C}$ in winter and $25.6-44.5^{\circ} \mathrm{C}$ in summer (GAMEP, 2015).

Sampling and laboratory analysis : In May 2015, four sampling sites were selected for collecting data from four irrigated farms to collect water, soil and anurans. Seven heavy metals viz., $\mathrm{Cu}, \mathrm{Cr}$, $\mathrm{Cd}, \mathrm{Ni}, \mathrm{Zn}, \mathrm{Pb}$ and $\mathrm{Mn}$ were chosen to study their spatial distribution in Al-Hayr area. Anuran samples were transferred alive on the same collection day to the laboratory of Zoology Department, College of Science, King Saud University. Anurans were then exposed to anesthesia until death by Ethanol $96 \%$ to obtain liver samples. The soil and anuran liver samples were oven dried separately for an hour to constant weight at $105^{\circ} \mathrm{C}$, then milled with a mortar and pestle. The samples were prepared by accurately weighing $0.1 \mathrm{~g}$ of dry matter into a dry and clean Teflon digestion beaker. A $2 \mathrm{ml}$ of nitric acid $(69 \% \mathrm{v} / \mathrm{v}) ; 6 \mathrm{ml}$ of hydrochloric acid ( $37 \% \mathrm{v} / \mathrm{v})$; and hydrofluoric acid $(40 \% \mathrm{v} / \mathrm{v})$ were added to the Teflon beaker. Samples were digested on the hot plate at $120-150^{\circ} \mathrm{C}$ for approximately $40 \mathrm{~min}$. The resulting digest was not clear, so it was filtered through Whattman filtered paper no.42. The filtered digest was transferred to a $15 \mathrm{ml}$ plastic volumetric flask and made up to mark using deionized water. A blank digest was carried out in the same way. Water samples were filtered by Whattman filtered paper no. 42, and then $15 \mathrm{ml}$ of filtered water for each sample was taken for assay. The analytical determination of trace metals was carried out by ICP-MS (Inductivity Coupled Plasma-Mass Spectrophotometer), type NexION 300D (Perkin Elmer, USA). Each test sample has been replicated three times, while it has 20 times readings out per each replicate. A standard sample was used to check the precision of the analysis (E. Merck standard).

Statistical analysis : Analysis of variance was used to evaluate the significant difference in the concentration of studied heavy metals with respect to different sites. A probability at level 0.05 or less was considered significant (Bailey, 1981). 


\section{Results and Discussion}

The perusal data revealed that heavy metal content in soil samples ranged from 8.86 to $10.91 \mu^{-1} \mathrm{Cu} ; 10.48$ to $20.3 \mu g^{-1}$ $\mathrm{Cr} ; 0.06$ to $0.161 \mu \mathrm{gg}^{-1} \mathrm{Cd} ; 11.13$ to $19.23 \mu \mathrm{gg}^{-1} \mathrm{Ni} ; 9.52$ to 27.4 $\mu g^{-1} \mathrm{Zn} ; 5.6$ to $7.14 \mu \mathrm{gg}^{-1} \mathrm{~Pb}$ and 53.6 to $97.95 \mu \mathrm{gg}^{-1} \mathrm{Mn}$ (Table 1). It was found that $\mathrm{Mn}$ and $\mathrm{Zn}$ contents was highest at all the study sites, which might be attributed to the discharge of agriculture and domestic treated wastewater stream which passes nearby the AlHayr farms (Madkour et al., 2015). The distribution of heavy metals in soil samples was noted in the following descending order $: \mathrm{Mn}>\mathrm{Zn}>\mathrm{Ni}>\mathrm{Cr}>\mathrm{Cu}>\mathrm{Pb}>\mathrm{Cd}$.

Heavy metal contents in the water samples ranged from 15.16 to $37.42 \mu \mathrm{gl}^{-1} \mathrm{Cu} ; 1.6$ to $2.61 \mathrm{\mu gl}^{-1} \mathrm{Cr} ; 0.05$ to $0.16 \mathrm{ugl}^{-1} \mathrm{Cd}$; 8.72 to $11.03 \mu \mathrm{gl}^{-1} \mathrm{Ni} ; 3.12$ to $5.65 \mu \mathrm{gl}^{-1} \mathrm{Zn} ; 0.15$ to $0.92 \mu \mathrm{gl}^{-1} \mathrm{~Pb}$ and 1.9 to $3.79 \mathrm{\mu g}^{-1} \mathrm{Mn}$ (Table 2). The highest value among the studied heavy metals was $\mathrm{Cu}$, but was below the toxic level.
Distribution of heavy metals in the water samples was found in the following descending order: $\mathrm{Cu}>\mathrm{Ni}>\mathrm{Zn}>\mathrm{Mn}>\mathrm{Cr}>\mathrm{Pb}>\mathrm{Cd}$. The soil and water results showed that no values appeared to be unusual if they were compared with guidance levels for unpolluted water and soil according to World Health organization and Council of the European Union standards (Adlassing et al., 2013). It was noticed that the concentration of heavy metals in soil samples were greater than those in water samples. This might be due to affinity of elements to react with suspended particular matters through sediments or soil (Gessey et al., 1984). High concentration of Cu may be, due to extensive use of pesticides containing copper compounds for agricultural purpose (Al-Weher, 2008). Statistically, the soil and water heavy metal values showed insignificant differences $(P>0.05)$.

The concentration of heavy metals in toads and frogs almost showed similar descending order: In toads: $\mathrm{Zn}>\mathrm{Cu}>\mathrm{Pb}>$ $\mathrm{Cr}>\mathrm{Mn}>\mathrm{Ni}>\mathrm{Cd}$, while in frogs: $\mathrm{Cu}>\mathrm{Zn}>\mathrm{Pb}>\mathrm{Cr}>\mathrm{Mn}>\mathrm{Ni}>\mathrm{Cd}$ (Tables

Table 1 : Mean concentration of heavy metals $\left({\mu g^{-1}}^{-1}\right)$ in soil samples collected from four sites of Al Hayr area, Riyadh, Saudi Arabia

\begin{tabular}{llllll}
\hline Heavy metals & Site1 & Site2 & Site3 & Site4 \\
\hline $\mathrm{Cu}$ & $9.2 \pm 1.17$ & $8.86 \pm 0.28$ & $10.7 \pm 0.35$ & $10.91 \pm 0.1$ & $16.13 \pm 0.25$ \\
$\mathrm{Cr}$ & $12.63 \pm 0.52$ & $10.48 \pm 0.4$ & $20.3 \pm 0.08$ & 0.91 & 14.88 \\
$\mathrm{Cd}$ & $0.12 \pm 0.002$ & $0.06 \pm 0.001$ & $0.092 \pm 0.003$ & $161 \pm 0.003$ \\
$\mathrm{Ni}$ & $11.13 \pm 0.57$ & $15.83 \pm 0.37$ & $19.23 \pm 0.89$ & $17.7 \pm 0.28$ & 0.11 \\
$\mathrm{Zn}$ & $27.12 \pm 1.17$ & $9.52 \pm 0.36$ & $6.62 \pm 0.18$ & $27.4 \pm 0.5$ & 15.97 \\
$\mathrm{~Pb}$ & $7.14 \pm 0.14$ & $6.62 \pm 0.04$ & $97.95 \pm 4.28$ & 7.04 & 20.38 \\
$\mathrm{Mn}$ & $53.6 \pm 0.0005$ & $78.89 \pm 2.08$ & & $78.8 \pm 1.88$ & 77.31 \\
\hline
\end{tabular}

Values are mean $\pm \mathrm{SD}$ of soil analysis

Table 2: Mean concentration of heavy metals $\left(\mu \mathrm{gl}^{-1}\right)$ in water samples collected from four sites of Al Hayr area, Riyadh, Saudi Arabia

\begin{tabular}{llllll}
\hline Heavy metals & Site1 & Site2 & Site3 & Site4 & Average \\
\hline $\mathrm{Cu}$ & $15.16 \pm 0.704$ & $20.68 \pm 2.1$ & $30.16 \pm 0.66$ & $37.42 \pm 1.404$ & 25.85 \\
$\mathrm{Cr}$ & $1.6 \pm 0.249$ & $2.61 \pm 0.191$ & $2.39 \pm 0.06$ & $1.33 \pm 0.001$ & 1.98 \\
$\mathrm{Cd}$ & $0.06 \pm 0.015$ & $0.16 \pm 0.023$ & $0.06 \pm 0.007$ & $0.05 \pm 0.007$ & 0.09 \\
$\mathrm{Ni}$ & $8.72 \pm 0.048$ & $11.03 \pm 0.332$ & $10.55 \pm 0.122$ & $10.43 \pm 0.084$ & 10.18 \\
$\mathrm{Zn}$ & $3.12 \pm 0.079$ & $5.32 \pm 0.081$ & $5.65 \pm 0.287$ & $4.89 \pm 0.075$ & 4.75 \\
$\mathrm{~Pb}$ & $0.15 \pm 0.021$ & $0.92 \pm 0.027$ & $0.71 \pm 0.018$ & $0.64 \pm 0.013$ & 0.61 \\
$\mathrm{Mn}$ & $1.9 \pm 0.02$ & $3.79 \pm 0.038$ & $2.94 \pm 0.47$ & $1.96 \pm 0.021$ & 2.65 \\
\hline
\end{tabular}

Values are mean $\pm S D$ of water analysis

Table 3: Mean concentration of heavy metals $\left(\mu \mathrm{gg}^{-1}\right)$ in toad liver samples collected from four sites of Al Hayr area, Riyadh, Saudi Arabia

\begin{tabular}{llllll}
\hline Heavy metals & Site 1 & Site 2 & Site 3 & Site 4 & Average \\
\hline $\mathrm{Cu}$ & $12.7 \pm 0.24$ & $24.3 \pm 0.16$ & $13.4 \pm 0.04$ & $24.3 \pm 0.67$ & 18.67 \\
$\mathrm{Cr}$ & $4.26 \pm 0.12$ & $17.6 \pm 0.06$ & $3.7 \pm 0.011$ & $7.2 \pm 0.167$ & 8.19 \\
$\mathrm{Cd}$ & $0.33 \pm 0.003$ & $0.372 \pm 0.001$ & $0.15 \pm 0.002$ & $0.133 \pm 0.008$ & 0.25 \\
$\mathrm{Ni}$ & $2.2 \pm 0.05$ & $5.6 \pm 0.04$ & $1.97 \pm 0.03$ & $2.98 \pm 0.08$ & 3.18 \\
$\mathrm{Zn}$ & $20.9 \pm 0.38$ & $22.74 \pm 0.07$ & $29.5 \pm 0.13$ & $35.3 \pm 0.91$ & 27.11 \\
$\mathrm{~Pb}$ & $10.9 \pm 0.05$ & $11.1 \pm 0.35$ & $3.2 \pm 0.014$ & $30.97 \pm 0.59$ & 14.04 \\
$\mathrm{Mn}$ & $3.83 \pm 0.05$ & $10.1 \pm 0.11$ & $7.7 \pm 0.08$ & $5.5 \pm 0.14$ & 6.78 \\
\hline
\end{tabular}

Values are mean $\pm \mathrm{SD}$ of toad's liver analysis 
Table 4 : Mean concentration of heavy metals $\left(\mu \mathrm{g} \mathrm{g}^{-1}\right)$ in frog liver samples collected from four sites of Al Hayr area, Riyadh, Saudi Arabia

\begin{tabular}{llllll}
\hline Heavy metals & Site1 & Site2 & Site3 & Site4 & Average \\
\hline $\mathrm{Cu}$ & N.S. & N.S. & $20.3 \pm 0.11$ & $33.96 \pm 0.33$ & 27.13 \\
$\mathrm{Cr}$ & N.S. & N.S. & $6.72 \pm 0.08$ & $9.42 \pm 0.115$ & 8.07 \\
$\mathrm{Cd}$ & N.S. & N.S. & $0.063 \pm 0.001$ & $0.053 \pm 0.006$ & 0.06 \\
$\mathrm{Ni}$ & N.S. & N.S. & $2.5 \pm 0.03$ & $4.44 \pm 0.04$ & 3.47 \\
$\mathrm{Zn}$ & N.S. & N.S. & $20.7 \pm 0.19$ & $28.6 \pm 0.29$ & 24.65 \\
$\mathrm{~Pb}$ & N.S. & N.S. & $10.4 \pm 0.047$ & $7.6 \pm 0.063$ & 9.0 \\
$\mathrm{Mn}$ & N.S. & N.S. & $2.51 \pm 0.023$ & $4.9 \pm 0.07$ & 3.7 \\
\hline
\end{tabular}

Values are mean \pm SD of frog's liver samples; $N$.S.: no samples were found in sites 1 and 2

Table 5 : Relative accumulation indices of heavy metals in the study area (for four sites)

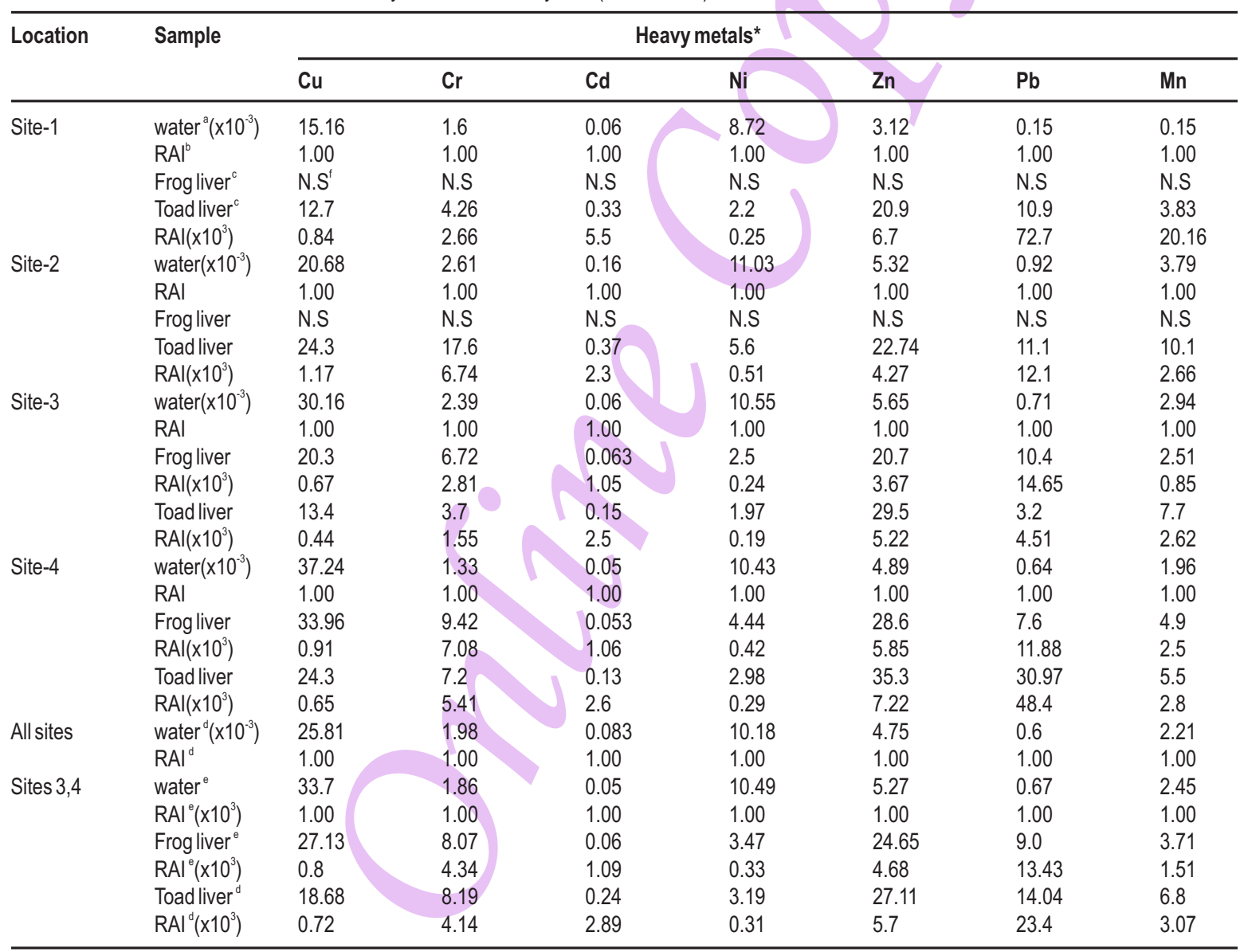

* Each value is a general mean for the concentration level of the corresponding metal based on results; ${ }^{2}$ Water concentration values, expressed as ( $\mu \mathrm{g}$ l' $\left.{ }^{1}\right)$, are divided by $10^{3}$ (unify the units) with anurans' liver concentration values; 'Relative accumulation indices (RAI) are results from dividing the other concentration values by the corresponding values of water concentration of each sample's site, (RAI values are multiplied by $\left.10^{3}\right) ;{ }^{\circ}$ Frog and Toad livers concentrations are expressed as $\mu \mathrm{g} \mathrm{g}{ }^{-1} ;{ }^{\mathrm{d}}$ The average for samples of all sites; ${ }^{e}$ The average for samples of sites 3 and $4 ;{ }^{\prime} \mathrm{N}$.S. no samples of frogs were found in sites 1 and 2

3 and 4). Anuran liver tissues were examined according to Ahmad et al. (2015), Tyokumbur and Okorie (2011) and Shaapera et al. (2013) who elucidated that frog liver accumulates higher concentrations of heavy metals than other organ tissues do (i.e., skin, muscle, kidneys or intestines). The average $\mathrm{Cu}$ and $\mathrm{Zn}$ concentrations in toads' liver samples were $18.67 \mu \mathrm{g} \mathrm{g}^{-1}$ and 27.11 
$\mu \mathrm{Mg}^{-1}$ respectively, while the average $\mathrm{Cu}$ and $\mathrm{Zn}$ concentration in frog liver samples were $27.13 \mu \mathrm{g} \mathrm{g}^{-1}$ and $24.65 \mu \mathrm{g} \mathrm{g}^{-1}$ respectively. Therefore, high Zn and Cu content in anuran liver tissues might be due to high levels of both elements in soil and water as mentioned before. It seems that the effect of heavy metals on anurans was the same due to insignificant difference between toads and frogs results $(P>0.05)$.

To determine the accumulation pattern of heavy metals in anurans' liver tissues, relative accumulation indices (expressed in terms of $\mathrm{x}$ times) were applied (Karadede et al., 2004; Mansour and Sidly, 2002). In this respect, values of heavy metals in water samples for each site was used as reference to determine the relative accumulation indices (RAI) for anurans' liver tissues. Accordingly, $\mathrm{Pb}$ showed the highest bioaccumulation rate in the liver tissues (13433 and 23400 times) for frogs and toads respectively, followed by Zn (4680 and 5707 times) for frogs and toads respectively, while Ni showed the lowest bioaccumulation rate (331 and 313 times) for frogs and toads, respectively (Table 5). This could be explained by the fact that $\mathrm{Pb}$ is non-essential for plants and animals and is a toxic element that can be harmful for living organisms, although animals usually show ability to accumulate large amount of $\mathrm{Pb}$ without visible changes in their appearance (Funtua et al., 2014). The high level of $\mathrm{Pb}$ in anurans' liver tissues could be attributed to the following: the anurans' glandular skin does not form a perfect barrier against heavy metals; anurans may feed on contaminated insects and other potential prey animals which are commonly found in wet habitats; or anurans may absorb and accumulate significant amount of $\mathrm{Pb}$ from the sediments of its habitats, in which, soil particles may be ingested during prey capture (Adlassing et al., 2013).Moreover, heavy metals could be accumulated in organism tissues due to intake of soil dust(Gupta et al., 2014). This could be expected due to anurans live in farms which are very closely to the industrial zone for cars scrap ( $2 \mathrm{~km}$ to the west). Other elements have been considered to be essential trace elements for animal health (Funtua et al., 2014;Nizaret al., 2015). The relative accumulation indices (RAI) order in anuran liver samples has the same following descending order: $\mathrm{Pb}>\mathrm{Zn}>\mathrm{Cr}>\mathrm{Mn}>\mathrm{Cd}>\mathrm{Cu}>\mathrm{Ni}$. This order might be explained by different uptake, metabolism and detoxification processes of heavy metals and it shows the same effect of heavy metals on anurans (Adlassing et al., 2013).

The relevance of this study was to evaluate seven heavy metal concentrations in AlHayr area. Findings showed different distribution of heavy metals among soil, water and anuran livers samples, but no values appeared to be unusual. Therefore, AlHayr was not considered as a heavy metals-polluted area, but a regular monitoring of heavy metals in soil and water should be undertaken, due to increasing anthropogenic activities which may effect on soil and water quality in near future.

\section{Acknowledgment}

The authors would like to extend their sincere thank to the Deanship of Scientific Research at King Saud University for funding of this research through the Research Group Project No. RGP-346.

\section{References}

Adlassnig, W., S. Sassmann, A. Grawunder, M. Puschenreiter, A. Horvath and M. Koller-Peroutka: Amphibians in metalcontaminated habitats. Salamandra, 49,149-158 (2013).

Ahmad, Z., K.A. Al-Ghamin, H.F.A. Al-Balawi, F. Al-Misned, S. Mahboob and E.M. Suliman: Accumulation of heavy metals in fish, Oreochrqmis niloticus and Poecilia latipinna and their concentration in water and sediment of dam lake of WadiNamar, Saudi Arabia. J. Environ. Biol.,36, 295-299 (2015).

Akram, A., M. Rais, M.A. Asadi, M.J. Jilani, S. Balouch, M. Anwar and A. Saleem: Do habitat variables correlate anurans abundance in arid terrain of Rawalpindi-Islamabad areas, Pakistan? J. King Saud Univ., 27, 278-283(2015).

Al-Weher, S.M.: Levels of heavy metal $\mathrm{Cd}, \mathrm{Cu}$ and $\mathrm{Zn}$ in three fish species collected from northern Jordan valley, Jordan. Jor. J. Biol. Sci., 1, 41-46 (2008).

Bailey, N.T.J.: Statistical Methods in Biology. $2^{\text {nd }}$ Edn., Edwarld Arnold, London (1981)

Funtua, M.A., E.B. Agbaji and A.A. Pam: Heavy metals contents in soil and some crops irrigated along the Bindare Stream Zaria-Kaduna state, Nigeria. Amer. Chem. Sci. J., 4, 855-864(2014).

General Authority of Meteorology and Environmental Protection (GAMEP), WMO-Riyadh Station no.: 40438, ICAO Code: OERY. (2015). Available at: http://www.pme.gov.sa/en/Weather/Local Weatherinfo/pages/temperature.aspx

Gessey, G.G., L. Borstad and P.M. Chapman: Influence of flow related events concentrations and phase distribution of metals in the lower Fraser River and a small tributary stream in British Columbia. Can. WaterRese., 18, 233-238(1984).

Gupta, S., V. Jena, N. Matic, V. Kapralova and J.S. Solanki: Assessment of geo-accumulation index of heavy metal and source of contamination by multivariate factor analysis. Int. J. Haz. Mat., 2, 18-22 (2014).

Halliday, T.R.: Why amphibians are important. International Zoo Yearbook. Zool. Soc. Lon., 42, 7-14 (2008).

Hopkins, W.A.: Amphibians as models for studying environmental changes. ILAR J., 48, 270-277(2007).

Karadede, H., S. Oymak and E. Unlu: Heavy metals in mullet, Liza abu, and catfish, Silurus triostegus from the Ataturk Dam Lake (Euphrates), Turkey. Environ. Int., 30, 183-188(2004).

Madkour, H.A., M.A. Abdelhalim, K.A. Obirikorang, A.W. Mohamed, N.A. Ahmed and A. El-Taher: Environmental implications of surface sediments from coastal lagoons in the Red Sea coast. J. Environ. Biol., 36, 1421-1427 (2015).

Mansour, S.A. and M.M. Sidky: Ecotoxicological studies. Heavy metals containing water and fish from Fayoum Governorate, Egypt. Food Chem., 78, 15-22(2002).

Nazir, R., M. Khan, M. Masab, H. Ur Rehman, N. Ur Rauf, S. Shahab, N. Ameer, M. Sajed, M. Ullah, M. Rafeeq and Z. Shaheen: Accumulation of heavy metals ( $\mathrm{Ni}, \mathrm{Cu}, \mathrm{Cd}, \mathrm{Cr}, \mathrm{Pb}, \mathrm{Zn}, \mathrm{Fe})$ in soil, 
water and plants and analysis of physio-chemical parameters of soil and water collected from Tanda Dam Kohat. J. Pharm. Sci. Res., 7, 89-97 (2015).

Serrano, A.E., R.A. Relyea, M. Tejedo and M.Torralva: Understanding of the impact of chemicals on amphibians: a meta-analytic review. Ecol.Evol., 2, 1382-1397(2012).

Shaapera, U., L.A. Nnamonu and I.S. Eneji: Assessment of heavy metals in Rana esculenta organs from River Guma, Benue State Nigeria. Am. J. Anal. Chem., 4, 496-500(2013).

Stepanyan, I.E., A.S.Tsarukyan and Y.P. Petrov: Effect of molybdenum, chrome and cadmium ions on metamorphosis and erythrocytes morphology of the marsh frog Pelophylax ridibundus (Amphibia: Anura). J. Environ. Sci. Technol., 4, 172-181(2011).

Tchounwou, P.B., C.G. Yedjou, A.K. Patlolla and D.J. Sutton: Heavy metals toxicity and the environment. US National Library of Medicine National Institutions of Health. (Online Article) doi: 10.1007/978-3-7643-8340-4_6(2012).

Tyokumbur, E.T. and T.G. Okorie: Macro and trace element accumulation in edible crabs and frogs in Alaro Stream Ecosystem, Ibadan, Nigeria. J. Res. Nat. Dev., 9, 439-446 (2011).

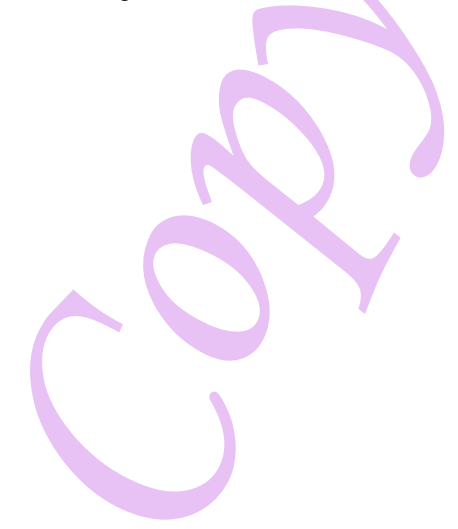

